\title{
FARMERS' ATTITUDE AND RICE ADDED VALUE BASED ON AGRICULTURAL MECHANIZATION IN EAST JAVA OF INDONESIA
}

\author{
Wahyuningsih Pipit ${ }^{\star}$, Susilo Acmadi, Wisnujati Nugrahini Susantinah \\ Master's Program of Agribusiness Management, Faculty of Agriculture, \\ Wijaya Kusuma University Surabaya, Indonesia \\ *E-mail: destawahyu@gmail.com
}

\begin{abstract}
Food consumption as rice commodities in Indonesia continues to increase yet inversely proportional to the number of workers. Unbalanced conditions between the needs and the number of workers affect production, so agricultural mechanization is necessary for achieving food self-sufficiency, whose goal is to improve the efficiency of farming resources, reduce yield losses and improve the quality of farm products. Using agricultural mechanization to enhance rice quality and added value will be more in post-harvest activities. The government facilitates farming tools and machinery that includes combining harvester machines, dryers, and rice milling machines to secure production, improve quality, added value, and competitiveness in rice commodities. The purpose of this study is to: 1). Analyze why farmers use farming tools and machinery to improve rice quality and added value; 2). Analyze farmers' attitude in using farming tools and machinery to enhance rice and added value quality, 3). Analyzing farmers' behaviour towards agricultural implements and machinery to improve rice and added value, and 4). Analyze the added value of rice. We researched 30 respondents in Tuban Regency using purposive sampling and analyzed it with qualitative and quantitative descriptive methods. The research results on farmers who have used farming tools and machinery such as combined-harvester machines, dryers, and rice milling in Tuban Regency are: 1) Farmers needed and accepted the use of combinedharvester and dryers in their farming activities; 2) Farmers have a positive attitude towards combined-harvester machines, dryers, and rice milling; 3) Using farming tools and machinery such as combined-harvester, dryers, and rice milling improve the quality of grain and final products in rice, affected behaviour changes on farmers to use mechanization in their farming activities, and 4) Grain processing into rice with a rice milling machine provides the added value of $\mathrm{Rp} .488 .65 / \mathrm{kg}$ or $71 \%$.
\end{abstract}

\section{KEY WORDS}

Combined-harvester machine, dryer, rice milling machine, quality, added value.

Agriculture is a strategic sector as a food provider. The agricultural industry is a determinant in supporting food security and has considerable and dynamic challenges both in the domestic and international sphere has. Several strategic steps are needed in answering challenges in the agricultural sector, where challenges include increasing farmers' incomes, meeting stable and affordable domestic needs, and business competition in the modernization era. Gevisioner et al. (2017) said that most of Indonesia's agricultural models are still in the upstream sector. However, the implementation of agricultural development has not been considered to increase farmers' income and welfare. The Ministry of Agriculture of the Republic of Indonesia (2019) in the Strategic Plan 2020 - 2024 conveyed that agricultural development policy focuses on modern agricultural development. Rifkian et al. (2017) described agricultural modernization itself shows a shift in the way or change in agricultural patterns covering various aspects of both natural resource development, agricultural institutions, technology, and regulation. This change is a picture of the transition from traditional to modern. Food needs show an increasing trend but inversely proportional to the increase in the number of workers, even the interest of the public to work in the world of agriculture is getting lower. Workers in the agricultural sector are dominated by the age group who are old or over the age of 50 years. Unbalanced conditions between the needs 
and the amount of labour affect production, so agriculture modernization is necessary for achieving food self-sufficiency. The use of farming tools and machinery today becomes the primary need for farmers in carrying out their activities.

Generally, in an agrarian society, farming modernization is shown by the use of technology. One of the technological developments currently widely felt by people living in rural areas is farming technology. Such technology is beneficial so that farmers can work more practically, efficiently, sparingly, and increase productivity (Selvia, S. et al., 2019). According to Handaka (2012), farming tools and machinery are inseparable and optimally used by small farmers and other users whose capabilities are limited. In its development, farming tools and machinery should be done integrally as a supporting agricultural activity system from upstream to downstream. The agricultural industry in Indonesia is still mostly filled with primary agricultural products. The transformation will provide adjustments to farmers from the indigenous side, community sausages, and value settings, the transition from the farm industry to agro-industry will make practical agriculture (Bafdal, 2012).

Farming tools and machinery are also needed to save production by reducing rice yields shrinkage, improving and improving rice quality, so there is a need for means in postharvest tools and machinery to increase farmers' added value and income. The Agricultural Research and Development Agency (2017) said that agricultural mechanization is expected to reduce the yield by $10.2 \%$. Production costs can also be saved up to $40 \%$ so that the increase in production is expected to increase by $10 \%$. The Ministry of Agriculture of the Republic of Indonesia and the Government of East Java Province from 2014 to 2020 have allocated post-harvest tools and machinery to farmers/farmer groups who conduct farming for rice commodities in 29 districts, including Tuban Regency. The policy in facilitating such facilities is carried out to save production, improve quality and standardization, increase added value and competitiveness of agricultural products. Therefore, this study aims to: 1). analyze why farmers use farming tools and machinery to improve rice quality and added value; 2). examine farmers' attitudes in using farming tools and machinery to enhance rice quality and added value; 3 ). analyze farmers' behaviour towards using farming tools and machinery to improve rice quality and added value, and 4). analyze the use of farming tools and machinery against the added value of rice.

\section{METHODS OF RESEARCH}

The research was conducted in Tuban Regency, East Java Province, by taking a location that has utilized post-harvest tools and machines in the form of combined-harvester machines, dryers, and rice milling machines (RMU) derived from government assistance and private property. The research was conducted from December 2020 - January 2021.

Table 1 - Formulation of value-added calculation

\begin{tabular}{|c|c|c|c|}
\hline \# & \multicolumn{2}{|c|}{ Variable } & Result \\
\hline I & \multicolumn{2}{|c|}{ Output Input and Price } & \\
\hline 1. & \multicolumn{2}{|c|}{ Product results (kg/day) } & (1) \\
\hline 2. & \multicolumn{2}{|c|}{ Raw materials (kg/day) } & (2) \\
\hline 3. & \multicolumn{2}{|c|}{ Labour (HOK/day) } & (3) \\
\hline 4. & \multicolumn{2}{|c|}{ Conversion factors } & $(4)=(1) /(2)$ \\
\hline 5. & \multicolumn{2}{|c|}{ Labour coefficient } & $(5)=(3) /(2)$ \\
\hline 6. & \multicolumn{2}{|c|}{ Average product price $(\mathrm{Rp} / \mathrm{kg})$} & (6) \\
\hline 7. & \multicolumn{2}{|c|}{ The average wage (Rp/day) } & (7) \\
\hline II & \multicolumn{2}{|c|}{ Revenue and Profit } & \\
\hline 8. & \multicolumn{2}{|c|}{ Raw material price $(\mathrm{Rp} / \mathrm{kg})$} & (8) \\
\hline 9. & \multicolumn{2}{|c|}{ Other input contributions $(\mathrm{Rp} / \mathrm{kg})$} & (9) \\
\hline 10. & \multicolumn{2}{|c|}{ Product value $(\mathrm{Rp} / \mathrm{kg})$} & $(10)=(4) \times(6)$ \\
\hline \multirow[t]{2}{*}{11.} & a. & Value-added (Rp/kg) & $(11 a)=(10)-(8)-(9)$ \\
\hline & b. & Value-added ratio & $(11 b)=(11 a) /(10) \times 100 \%$ \\
\hline \multirow[t]{2}{*}{12.} & a. & Labour rewards & $(12 a)=(5) \times(7)$ \\
\hline & b. & Labour section & $(12 b)=(12 a) /(11 a) \times 100 \%$ \\
\hline \multirow[t]{2}{*}{13.} & a. & Advantages & $(13 a)=(11 a)-(12 a)$ \\
\hline & \multirow{3}{*}{\multicolumn{2}{|c|}{ Return of The Owner of Production Factors }} & $(13 b)=(13 a) /(11 a) \times 100 \%$ \\
\hline III & & & \\
\hline \multirow[t]{4}{*}{14} & & & $(14)=(10)-(8)$ \\
\hline & a. & Labour income & $(14 a)=(12 a) /(14) \times 100 \%$ \\
\hline & b. & Other Input Donations & $(14 b)=(9) /(14) \times 100 \%$ \\
\hline & c. & Advantages & $(14 c)=(13 a) /(14) \times 100 \%$ \\
\hline
\end{tabular}

Source: Primary Data (2020). 
This study used the purposive sampling method to determine the subject. Respondents were selected from farmers/farmer groups who have used combined-harvester machines, dryers, and milling machines in their farming activities. Data were collected from 30 respondents as samples using interviews and a list of questions (questionnaires). The data analysis used is descriptive qualitative to analyze the reasons for farmers' acceptance of farming tools and machinery, attitudes, and changes in farmer behaviour on farming tools and machinery. The amount of added value of grain processing into rice was calculated quantifiably using the Hayami method value-added analysis. Formulation of value-added calculation as presented in Table 1.

\section{RESULTS AND DISCUSSION}

Reasons for Farmers in the Use of Farming tools and Machinery in Tuban Regency. The utilization of farming tools and machinery in the Tuban regency began to increase in 2015. The program implemented the Value-Added Improvement and Competitiveness Program of Agricultural Products to increase added value, increase farmers' income and welfare. In the policy's performance, several strategies: a) improving the quality of products and processing of raw materials into semi-finished, and; b) increase the price of agricultural commodities and provide a proportional profit sharing for farmers. Regarding rice commodities, facilities and infrastructure in post-harvest activities are needed to improve grain and rice quality. Along with the advancement of farming technology, rice quality improvement is primarily influenced by good post-harvest handling during harvesting and throes, drying, and milling, which is currently supported by mechanization equipment in the form of combined-harvester machines, dryers, and rice milling.

Table 2 - Farmer's Acceptance of Combined-harvester Machine

\begin{tabular}{|l|l|l|l|}
\hline No & Category & Number of People & Percentage \\
\hline 1 & Received & 30 & $100 \%$ \\
\hline 2 & Less Received & 0 & $0 \%$ \\
\hline & & 30 & $100 \%$ \\
\hline
\end{tabular}

Source: Primary Data (2020).

The table shows that the percentage of farmers' acceptance of combined-harvester machines is $100 \%$, which means farmers receive it.

Table 3 - Farmer's Acceptance of Dryer

\begin{tabular}{|l|l|l|l|}
\hline No & Category & Number of People & Percentage \\
\hline 1 & Received & 30 & $100 \%$ \\
\hline 2 & Less Received & 0 & $0 \%$ \\
\hline & & 30 & $100 \%$ \\
\hline
\end{tabular}

Source: Primary Data (2020).

The table shows that the percentage of farmers' acceptance of dryers is $100 \%$, which means farmers receive it.

Table 4 - Farmer's Acceptance of Rice Milling Machine

\begin{tabular}{|l|l|l|l|}
\hline No & Category & Number of People & Percentage \\
\hline 1 & Received & 30 & $100 \%$ \\
\hline 2 & Less Received & 0 & $0 \%$ \\
\hline & & 30 & $100 \%$ \\
\hline
\end{tabular}

Source: Primary Data (2020).

The condition also answers the results of Swastika's research (2012), which states that mechanization in post-harvest activities is widely available but still has various obstacles in its application at the farmer level. Even though advanced technology in post-harvest handling 
is quite widely available, such as harvesting technology, throes, drying, or rice milling, its application at the farmer level still faces limited constraints. It includes farmers' knowledge of the technology and the lack of farmers' ability to procure post-harvest tools and machinery. So strategic policies are needed to address this.

Table 5 - Perception of Farmers in the Selection of Farming tools and Machinery in Tuban Regency

\begin{tabular}{|l|l|l|l|}
\hline № & Category & Useful & Efficient \\
\hline 1 & Combined-harvester & $97 \%$ & $97 \%$ \\
\hline 2 & Dryer & $97 \%$ & $97 \%$ \\
\hline 3 & Rice Milling & $97 \%$ & $97 \%$ \\
\hline
\end{tabular}

Source: Primary Data (2020).

The data shows that the need to use farming tools and machinery for three types of machinery categories is considered valuable and efficient for farmers. The result from 30 respondents shows $97 \%$ of farmers stated that combined-harvester equipment, dryers, and rice milling machines are helpful and efficient for farmers. It also shows that the need for the use of farming tools and machinery for three types of machinery categories is considered valuable and efficient for farmers.

The result from 30 respondents shows that $97 \%$ of farmers stated that combinedharvester equipment, dryers, and rice milling machines are helpful and efficient for farmers. In line with Apiors et al. (2016) research in Ghana, the adoption of technology by local farmers occurred in 2010-2015 following the increasing development of farming machinery types at the site. The study shows a dynamic perception of farmers in cultivation activities/farming that is closely related to the availability/access to farming machines.

The availability of farming machines and easy access are very influential factors in farming activities. With the availability of the type and number of the farming machine, access will be easier. Purwantini research (2018) also explained that almost all showed increased availability and access to harvest and the post-harvest farming machine in the sample village during the study. Increased access is on positive values (or a small percentage has no neutral impact).

Factors that provide influence are the type of farming machine needed by farmers, the accuracy of the amount, concentration of distribution of the recipient's location, the time of supply of the suitable farming machine, and the farming machine's performance. The development condition of farming tools and machinery in the Tuban Regency related to improving rice quality shows that the existence of farming tools and machinery is widely known and used by farmers in improving the quality of grain and rice. Easy access to such tools and machinery and the development of technology accepted and adopted by Tuban farmers make farming tools and machinery a vital part of their farming activities.

Farmer Attitude in The Use of Farming tools and Machinery to Improve the Quality and Added Value of Rice in Tuban Regency. The data showed that the average output of farmers applied to the utilization of farming tools and machinery is a positive attitude (strongly agreed) with the percentage of $70 \%$ for the use of combined-harvester, $67 \%$ for the benefit of dryers, and 53\% for rice milling machines as in Table 6, Table 7, and Table 6.

Table 6 - Farmer's Attitude Towards the Use of Combined-harvester Machine in Improving Rice Quality and Added Value in Tuban Regency

\begin{tabular}{|c|c|c|c|c|c|}
\hline № & Category & Score & Interval & Number of People & Percentage \\
\hline 1 & Strongly disagree & 1 & $(30-54)$ & 1 & $3 \%$ \\
\hline 2 & Disagree & 2 & $(55-78)$ & 2 & $7 \%$ \\
\hline 3 & Netral & 3 & $(79-102)$ & 1 & $3 \%$ \\
\hline 4 & Agree & 4 & $(102-126)$ & 5 & $17 \%$ \\
\hline 5 & Strongly agree & 5 & $(127-150)$ & 21 & $70 \%$ \\
\hline & & & & 30 & $100 \%$ \\
\hline
\end{tabular}

Source: Primary Data (2020). 
Table 6 shows that 21 respondents $(70 \%)$ and interval value $(127-150)$ strongly agree. With an index of $89 \%$, farmers in Tuban District showed a strongly agreed attitude that combined-harvester machines could improve rice quality and added value in Tuban Regency.

Table 7 - Farmer's Attitude Towards the Use of Dryer Improving Rice Quality and Added Value in Tuban Regency

\begin{tabular}{|c|c|c|c|c|c|}
\hline № & Category & Score & Interval & Number of People & Percentage \\
\hline 1 & Strongly disagree & 1 & $(30-54)$ & 1 & $3 \%$ \\
\hline 2 & Disagree & 2 & $(55-78)$ & 2 & $7 \%$ \\
\hline 3 & Netral & 3 & $(79-102)$ & 0 & $0 \%$ \\
\hline 4 & Agree & 4 & $(102-126)$ & 7 & $23 \%$ \\
\hline 5 & Strongly agree & 5 & $(127-150)$ & 20 & $67 \%$ \\
\hline & & & & 30 & $100 \%$ \\
\hline
\end{tabular}

Source: Primary Data (2020)ю

Table 7 shows that out of 20 respondents or with a percentage of $67 \%$ and interval value (127 - 150) strongly agree. With an index of $89 \%$, farmers in Tuban District showed a strongly agreed attitude that dryers could improve rice quality and added value in Tuban Regency.

Table 8 - Farmer's Attitude Towards the Use of Rice Milling Machine in Improving Rice Quality and Added Value in Tuban Regency

\begin{tabular}{|c|c|c|c|c|c|}
\hline No. & Category & Score & Interval & Number of People & Percentage \\
\hline 1 & Strongly Disagree & 1 & $(30-54)$ & 1 & $3 \%$ \\
\hline 2 & Disagree & 2 & $(55-78)$ & 2 & $7 \%$ \\
\hline 3 & Hesitate (Neutral) & 3 & $(79-102)$ & 0 & $0 \%$ \\
\hline 4 & Agree & 4 & $(102-126)$ & 11 & $37 \%$ \\
\hline \multirow[t]{2}{*}{5} & Strongly Agree & 5 & $(127-150)$ & 16 & $53 \%$ \\
\hline & & & & 30 & $100 \%$ \\
\hline
\end{tabular}

Source: Primary Data (2020).

Table 8 shows that 16 respondents or with a percentage of $67 \%$ and interval value (127 - 150) strongly agree. With an index of $86 \%$, farmers in Tuban District showed a strongly agreed attitude that rice milling machines could improve rice quality and added value to Tuban Regency farmers.

Changes in Farmers' Behaviour in the Use of Farming tools and Machinery to Improve the Quality and Added Value of Rice in Tuban Regency. According to farmers in Tuban Regency, harvest equipment in the form of combined-harvester machines is considered very useful because of the diminishing number of workers in the agricultural sector in Tuban Regency, and mechanization function is needed so that there is no delay in harvesting. One problem faced by farmers is the increased cost of farming because of increasing labour wages due to limited labour availability and decreased crop yields because of longer harvest time. Technological innovations in harvesting and threshing into one in a series of combinedharvester machines show that the equipment is efficient to use at the time of harvest and threshing.

Table 9 - Changes in Farmer Behaviour After Combined-harvester Machine Usage

\begin{tabular}{|l|l|l|l|}
\hline № & Category & Number of People & Percentage \\
\hline 1. & Changed behaviour & 29 & $97 \%$ \\
\hline 2. & Unchanged behaviour & 1 & $3 \%$ \\
\hline
\end{tabular}

Source: Primary Data (2020).

Based on Table 9, farmers experience a change in behaviour after utilizing combinedharvester machines to improve the rice quality and added value with a percentage value of 
97\%. At first, the combined-harvester device was denied because it was considered to take away the harvesting farmers' job. But furthermore, farmers are in desperate need of this technology due to limited labour farmers cause crop delays, temporary buildup and cause a considerable shrinkage and affect the quality of grain produced.

Table 10 - Comparison of Harvesting Procedure Against Performance

\begin{tabular}{|c|c|c|c|}
\hline № & Parameter & $\begin{array}{l}\text { Harvesting procedure } \\
\text { Manual }\end{array}$ & Combined-harvester \\
\hline 1 & Duration & $8-10$ hours $/ \mathrm{Ha}$ & $4-6$ hours/Ha \\
\hline 2 & Total labour/day & $20-25$ persons $/ \mathrm{Ha}$ & 3 - 4 persons $/ \mathrm{Ha}$ \\
\hline 3 & Labour cost/day rent $(R p)$ & 4.000 .000 & 2.400 .000 \\
\hline
\end{tabular}

Source: Primary Data (2020).

Table 10 shows that the use of combined-harvester machines is considered beneficial and needed by farmers because the harvest time is shorter and can handle a complete harvest. It also reduces the risk of shrinkage scattered due to crop delays, and grain yields are cleaner because the follow-up of empty grains and dirt is relatively minimal. In operating the combined-harvester machine, the average amount of 3-4 labour can cope with the harvest time of 4-6 hours per hectare. It is considered more efficient than the manual system both from time efficiency, meet labour limitations.

Table 11 - Grain Quality Group Guidelines

\begin{tabular}{|c|c|c|c|}
\hline № & Category & Max Moisture Content & Empty content \\
\hline 1 & Milled Dry Grain & $\max 14 \%$ & $\max 35 \%$ \\
\hline 2 & Harvested Dry Grain & $19-25 \%$ & $7-10 \%$ \\
\hline 3 & Beyond Quality Grain 1 & $19-25 \%$ & $11-15 \%$ \\
\hline 4 & Beyond Quality Grain 2 & $26-30 \%$ & $11-15 \%$ \\
\hline
\end{tabular}

Source: Regulation of the Minister of Agriculture (2012)ю

The use of a combined-harvester machine also influences Dry Grain Harvest (DGH) quality because the harvest is cleaner, where the platforming technology in the combinedharvester is equipped with a blower/fan to remove dirt and empty grains. With a combinedharvester machine, the following hollow grains are relatively small or $<5 \%$. In terms of quality, they refer to Regulation of the Minister of Agriculture No. 27/Permentan/PP.200/4/201 concerning Guidelines for The Purchase Price of Grain and Rice Outside Quality by the Government in Table 11 shows relatively small empty levels and above quality standards. The impact of using a combined-harvester machine on the price of Dry Grain Harvest (DGH) is given a higher price with a price range of Rp. 300 - Rp. 400/kg compared to the price of grain harvested manually.

The study also shows that type and brand of the combined-harvester machine also affect the quality of grain produced. The majority of farmers choose to use a large variety of combined-harvester because it is considered faster in harvesting and cleaning grain yields. Technically, the use of large combined-harvesters is supported by a large drive motor so that the performance of the machine in the harvesting and threshing process is more effective.

Dryer Rice Quality Problems Are Influenced by the Quality of Dry Milled Grain (DMG). One effort to process grain into rice is drying grain with good moisture content $(14 \%)$ so that it is safe to store for an extended period and reduce the number of broken grains when grinding. According to farmers in Tuban Regency, the scourge for farmers, especially at the peak of harvest and harvest in the rainy season, is the drying process.

Harvesting at the peak season and the rainy season would take proper post-harvest handling for drying. The delay in the drying process would increase the risk of decreasing grain quality because of the high water content. It will affect the selling price of grain/rice owned by farmers to fall below the government regulations Cost of Goods Sold.

The majority of the Tuban Regency farmers are drying grain through a process that still relies on the sun's heat. In hot weather conditions, the process of drying grain can be done in 
a faster time. Yet, in rainy conditions drying with sunlight takes longer (more than three days), which causes lower grain quality due to high water content. The grain would grow and result in lower selling prices. Besides, grain with drying delay will affect ground rice quality because the colour will become opaque or brownish, resulting in rice's selling price falling.

Since 2015, the drying stage's grain problem can be solved by utilizing the dryer from government grants' facilitation, yet still very few amounts. In 2018, the facilitation of rice dryers from the government began to be many, and some farmers also adopted by making their dryers in the form of bed dryers (tubs) that use liquid gas (LPG). Government facilitates the dryers in the form of vertical dryers with 6 tons and 10 tons capacity. Until 2020, the facilitation of dryers in the Tuban Regency increased, and farmer groups began to venture to purchase dryers themselves by utilizing the Funds of People's Business Credit (KUR) at Bank Rakyat Indonesia or Bank Nasional Indonesia or Credit Investrasi from Bank Jatim. The existence of dryers in the Tuban Regency is increasingly needed and considered helpful in the post-harvest handling process to maintain grain quality. The experience of farmers shows that the drying process using a dryer is considered more efficient because it requires a shorter time and less labour than manual drying. The costs incurred by farmers for the drying process using a dryer range from Rp. 125 up to $\mathrm{Rp} .150 / \mathrm{kg}$, and the value is smaller than the cost spent on drying with sunlight that costs Rp. 175 up to Rp. 200/kg. The price will increase in case of harvest or peak harvest and the rainy season up to Rp. $250 / \mathrm{kg}$ if the drying time becomes long (more than three days) as in Table 12.

Table 12 - Comparison of Drying Methods to Performance

\begin{tabular}{|l|l|l|l|}
\hline № & Parameters & $\begin{array}{l}\text { Harvesting procedure } \\
\text { Drying floor }\end{array}$ & Dryer machines \\
\hline 1 & Capacity & $3-5$ tonnes & $6-10$ tonnes \\
\hline 2 & Duration & $2-3$ days & $8-12$ hours \\
\hline 2 & Number of labour/day & 5 persons/process & $3-4$ persons $/$ process \\
\hline 3 & Labour cost/process & Rp. $175-$ Rp. $250 / \mathrm{kg}$ & Rp. $150-175 / \mathrm{kg}$ \\
\hline
\end{tabular}

Source: Primary Data (2020)ю

Grain dryers used by farmers in Tuban Regency have a processing capacity of 6 tons and 10 tons/process. The drying time takes about 8-10 hours, depending on the water content of the rice fields that are processed. The dryer is used automatically by using the panel that has been set. According to farmers, Dry Milled Grain (DMG) processed with the machine has a good impact on grain quality. Using the dryer has eliminated empty grains and dirt at the process input, so that produced dry milled grain is clean and provides higher rice yield. Also, the drying process using the machine provides an even moisture content because it works continuous dryer and constant, which will automatically stop at the predetermined moisture content for rice quality (14\%).

Table 13 - Changes in Farmer Behaviour Post Dryer's Use

\begin{tabular}{|l|l|l|l|}
\hline № & Category & Number of people & Percentage \\
\hline 1. & Changed behaviour & 29 & $97 \%$ \\
\hline 2. & Unchanged behaviour & 1 & $3 \%$ \\
\hline
\end{tabular}

Source: Primary Data (2020)ю

Table 13 shows that farmers experience a change in behaviour after utilizing dryers to improve the rice quality and added value with a percentage value of $97 \%$.

Rice milling equipment is a critical point in producing quality rice. Out of 30 research respondents, rice milling equipment managed by farmers in Tuban Regency has an average process capacity of $1 \mathrm{ton} /$ hour. The rice milling consists of huskers and polishers configured as a single or separated unit in one machine. Other configurations are separators, but not all mills have this equipment. Rice milling equipment is needed and considered helpful for farmers to increase the added value of rice to rice so that farmers' income in selling it is 
higher than sales in the form of dry grain harvest or dry milled grain. With the rice milling, farmers can manage the crop from upstream to downstream so that farmers' profit is higher.

Table 14 - Changes in Farmer Behaviour After Use Rice Milling Machine

\begin{tabular}{|l|l|l|l|}
\hline № & Category & Number of people & Percentage \\
\hline 1. & Accepted & 30 & $100 \%$ \\
\hline 2. & Less accepted & 0 & $0 \%$ \\
\hline
\end{tabular}

Source: Primary Data (2020).

Table 14 shows that farmers experience a change in behaviour after utilizing rice milling machines to improve the quality and added value of rice with a percentage value of $100 \%$. The average farmer stated that the use of rice milling machines with a minimal configuration in the form of huskers and polishers would provide more value than farmers selling grain in the form of Dry Grain Harvest (GKP) or Dry Milled Grain (DMG). Changes in farmers' behaviour towards mechanization technology show that combined-harvester machines, dryers, and rice milling machines are needed and valuable. The behaviour change is also influenced by farmers' perception of the use of farming tools and machinery that can accept and require the tool's function. Changes in the behaviour of farmers who have used combined-harvester machines, dryers, and rice milling machines have a significant influence on the profit gained and the speed of obtaining the value that directly affects farmers' welfare. The research results in Tuban Regency are not much different from the research conducted by Nurwahyuningsih et al. (2015) Cikoro Village, Gowa Regency, South Sulawesi. The study results illustrate that the modernization of agriculture through tools and machinery impacts farmers' lives in Kelurahan Cikoro in terms of the economy, and livelihoods are increasing.

Table 15 - Processing Value Added Calculation Average Grain Becomes Rice

\begin{tabular}{|c|c|c|}
\hline № & Description & Formula \\
\hline \multicolumn{3}{|c|}{ I. Input, Output, and Price } \\
\hline 1. & Yield (kg/day) & $4.655,33$ \\
\hline 2. & Raw materials $(\mathrm{kg} /)$ & $7.166,67$ \\
\hline 3. & Labour (person/day) & 4,13 \\
\hline 4. & Conversion factor $(1: 2)$ & 0,6497 \\
\hline 5. & Labour coefficient (3:2) & 0,0011 \\
\hline 6. & Average product price $(\mathrm{Rp} / \mathrm{kg})$ & $9.396,67$ \\
\hline 7. & Wage rate (Rp/day) & $96.866,67$ \\
\hline \multicolumn{3}{|c|}{ II. Value-added and Profit } \\
\hline 8. & Raw material price $(\mathrm{Rp} / \mathrm{kg})$ & $5.588,33$ \\
\hline 9. & Other inputs contribution (Rp/kg) & 27,68 \\
\hline 10. & Product value $(4 \times 6)(\mathrm{Rp} / \mathrm{kg})$ & $6.104,67$ \\
\hline \multirow[t]{2}{*}{11.} & Value-added (10-8-9) (Rp/kg) & 488,65 \\
\hline & Value-added ration $(11 \mathrm{a} / 10)(\%)$ & $8 \%$ \\
\hline \multirow[t]{2}{*}{12.} & Labour benefits $(5 \times 7)(\mathrm{kg})$ & 94,08 \\
\hline & Labour share $(12 \mathrm{a} / 11)(\%)$ & $29 \%$ \\
\hline 13. & Profit (11a - 12a) & 394,57 \\
\hline 13. & Profit rate $(13 a / 11 a)(\%)$ & $71 \%$ \\
\hline \multicolumn{3}{|c|}{ III. Return of Production Factors } \\
\hline \multirow[t]{4}{*}{14.} & Margin $(14=10-8)$ & 516,33 \\
\hline & Labour income (12a/14) (\%) & $26 \%$ \\
\hline & Other input contributions $(9 / 14)(\%)$ & $8 \%$ \\
\hline & Profit (13a/14) (\%) & $66 \%$ \\
\hline
\end{tabular}

Source: Primary Data Analysis, 2020.

Table shows that raw materials are obtained from the local community's agricultural products (farmer groups and surrounding communities). Grain raw materials are inputs, and purchases cost an average of Rp. 5,588.33/kg. The average amount of raw materials used is 
$7,166.67 \mathrm{~kg}$ of grain/day. Grain processing activities show that the average figure is 4.13 or carried out by a workforce of 4 people. The average labour wage per day is Rp 96,866.67 per labour. The average farmer in processing grain into rice using raw materials as much as $7,166.67 \mathrm{~kg} / \mathrm{day}$, producing rice products as much as $4,655.33 \mathrm{~kg} / \mathrm{day}$. The value of the conversion factor in the business is 0.6497 . In other words, this value indicates a milled yield of $0.6497 \mathrm{~kg}$ of rice or with a yield rate of $64.97 \%$. The labour coefficient is 0.0011 working day. It means to process $1 \mathrm{~kg}$ of grain needed labour as much as 0.0011 working day.

The price of rice products in this study was Rp 9,369.67/ $\mathrm{kg}$. Meanwhile, the average wage per day is Rp. 96,8999.67 per worker. Input (raw materials) used is dry milled grain obtained from farmers with a raw material price of $\mathrm{Rp} 5,588.33 / \mathrm{kg}$. Other input contributions amounted to $27.68 / \mathrm{Kg}$. The added value of $\mathrm{Rp} 488.65 / \mathrm{kg}$ of raw materials means each processing of one kilo of grain into rice will provide the added value of $R p$ 488.65. The amount of the increase in value is still a gross added value because there is a share for labour income in it. With the value-added ratio of $8 \%$, it can be interpreted that every Rp. 100 product value will be obtained an added value of $\mathrm{Rp} \mathrm{8.0.} \mathrm{Labour} \mathrm{benefits} \mathrm{are} \mathrm{Rp} 94.08 / \mathrm{kg}$ of raw materials.

It means a kilo of raw materials requires a labour reward of Rp 94.08 (a labour share of $29 \%$ ). The profit from rice processing was Rp 394.57/kg of raw materials (71\% profit rate).

At Rp 516.33/kg margin, it is the largest return in the company's profit of $66 \%$ or $\mathrm{Rp}$ $394.57 / \mathrm{kg}$ of raw materials. Labour wages ranked second at $26 \%$ or $\mathrm{Rp} 94.08 / \mathrm{Kg}$ and other input contributions of $8 \%$ with a value of $\mathrm{Rp} 27.68 / \mathrm{kg}$ of raw materials.

The previous research conducted by Patiung (2015) in Tuban Regency showed that rice quality would be determined in the polishing process. High-quality rice shows a bright and shiny physical appearance. The rice is produced from a suitable mill with a high degree of whiteness. In its recommendations, rice milling becomes an essential part of rice postharvest shrinkage results. The increase in revenue obtained from the processing industry, especially in rice milling, can be analysed to determine its profit and feasibility. Food crop products will have added value if further processing efforts are carried out. In rice commodities, the opportunity to increase value is done through agro-industry in rice milling (RMU). The business is a crucial stage of obtaining added value from the final product sale (Elizabeth, 2019).

The research results in Thailand conducted by Rerkasem (2017) also showed that technology development is beneficial in improving rice yields because the market appreciates the quality produced. By combining harvest management, mechanical drying will help raise Thai rice's value by increasing the whole milling output and getting higher prices. Technological developments have helped add value as well as segments of Thailand's rice market.

The results show that the processing of grain into rice by farmers who have made a lot of progress in using post-harvest technology in the Tuban Regency can benefit them, farmers can enjoy the most significant part of the added value created on capital and management. The benefits enjoyed by farmers can help for business sustainability to continue to run sustainably and provide additional income levels so that farmers are more prosperous.

Added value in the rice industry in Tuban is highly possible to be leveraged by improving rice quality from medium to premium. Research by Puspitasari et al. (2018) in Perum Bulog North Sulawesi and Gorontalo suggests that the increase in premium rice sales is influenced predominantly by product quality variables. By improving the quality of premium rice, the sales volume will increase, which means that quality positively affects sales. By upgrading rice quality, farmers in Tuban will increase added value because the price of premium rice will add to the value received by farmers. In other words, the performance of products or services from farmers or mills is directly affected by the quality produced. Agricultural businesses will achieve economic scale if a decrease follows the added value in production costs. The achievement will encourage farmer groups in Tuban Regency to expand their business to increase income and improve their standard of living. 


\section{CONCLUSION}

From research conducted on farmers who have utilized agricultural tools and machinery in the form of combine harvester machines, dryers and rice milling in Tuban Regency to improve the quality and added value of rice in Tuban Regency, the following conclusions are obtained:

- Farmers have a good perception of the use of combined-harvester machines, dryers and rice milling because it is perceived to provide benefits and become necessary in harvesting activities and threshing, drying and milling with a percentage of $97 \%$. These three types of farming tools and machinery are considered efficient for time, labour, and farming costs. Farmers need these tools;

- Farmers have a positive attitude towards the utilization of combined-harvester machines, dryers and rice milling. Farmers' attitude towards the use of combine harvester machines in improving the rice quality and added value in Tuban Regency has an index of $89 \%$, the use of dryers by $89 \%$, and milling machines by $86 \%$;

- The use of agricultural tools and machinery in the form of combined-harvester machines is considered to improve the quality of dry rice grain, dryers are considered to improve the quality of the dry milled grain, and rice milling is believed to enhance the rice quality. The rice quality produced by farmers is determined by the dry milled grain quality and the dry rice grain. The impact gives behaviour changes for farmers to use mechanization in their farming activities;

- Processing grain into rice gives added value to rice commodities compared to if it sold in the form of grain. The addition is the added value to the product. The obtained added value by farmers averaged Rp.488.65/kg or $71 \%$, with the profit acquisition of Rp. $516.33 / \mathrm{kg}$ or $66 \%$. The increase in added value is influenced by raw materials, labour, and material prices.

Based on the results of the study, we recommend:

- It is necessary to support farm activities from upstream to downstream with mechanization technology to increase farmers income;

- The use of agricultural tools and machinery and the development of positive technology for farmers require assistance to improve the farmers' capabilities through extension activities, training, and education so that professional farmers' human resources are formed independent and competitive;

- To strengthen the farmers' institutional as managers of agricultural tools and machinery at the farmer group level as an organization requires knowledge management involving knowledge planning, production, and technology dissemination to improve farmers' resources quality;

- Researches related to agricultural technology and increased added value are expected to become a reference or corporate farming so that the success of agricultural development can be measured using economic growth indicators set based on the reference results.

\section{LIMITATIONS}

This study has limitations due to the research conducted in the condition of the Covid 19 pandemic, so field surveys and interviews become less in-depth with respondents. The number of respondents selected by 30 people needs to be added for further research to describe the actual situation. The information provided by respondents through questionnaires also requires repetitions through interviews due to different perceptions and opinions on the questionnaire content's purpose.

With these limitations, it is recommended to the following researchers to be able to thoroughly examine the efficiency of each agricultural tool and machinery use, so the field conditions could clearly be defined, and the factors related to increasing farmers' income could be known. 


\section{REFERENCES}

1. Appiors, E.K., John K.M. Kuwornu, and George T-M. Kwadzo. 2016. Effect of Mechanisation Use Intensity on The Productivity of Rice Farms in Southern Ghana. Acta Agriculture Slovenica 107 (2):439.

2. Agricultural Research and Development Agency of the Ministry of Agriculture of the Republic of Indonesia (2017). Modern Horticultural Mechanization Technology Helps Increase Agricultural Production. http://www.litbang.pertanian.go.id/info-aktual/3002/. Retrieved September 26, 2020. 2 p.m.

3. Bafdal, Nurpiliham. 2012. Introduction to Agricultural Industry Technology. Unpad Press. Bandung.

4. Elizabeth, R., 2019. Increasing Competitiveness of Food Crops Through Acceleration of Agro-industry and Institutional Empowerment of Agriculture. Journal of AgribusinessMinded Scientific Community Thinking. July 2019. 5(2): 379-394

5. Gevisioner, Rudi Febriamansyah, Ifdal and Suardi Tarumun. 2017. Failure of Agricultural Development to Improve Farmers' Welfare in Indonesia. http://pasca.unand.ac.id/id/prosiding-seminar-nasional-perencanaan-pembangunaninklusif-desa-kota

6. Handaka. 2012. Contribution of Agricultural Mechanization and Post-Harvest Technology in Agribusiness Systems and Businesses. Paper on Expose and Seminar on Mechanization of Agriculture and Post-Harvest Technology; 2002 Jul 30-31. Malang, Indonesia.

7. Hayami Y, Kawagoe, Morooka, and Siregar. 1987. Agricultural Marketing and Processing in Upland Java: A Perspective from A Sunda Village. CGPRT Bogor. Ch. 6. http://www.uncapsa.org/Publication/cg8.pdf. Retrieved October 23, 2020. Pp.40-46

8. Ministry of Agriculture. 2017. Regulation of the Minister of Agriculture No. 31/Permentan/PP.130/8/ 2017 on Rice Quality Class.

9. Ministry of Agriculture of the Republic of Indonesia. 2019. Strategic Plan of the Ministry of Agriculture 2019 - 2024. (ID): Planning Bureau of the Secretariat General of the Ministry of Agriculture. Jakarta.

10. Notoatmodjo. 2003. Research Methods, Theories and Applications. Pt. King Grafindo Persada. Jakarta.

11. Nurwahyuningsih, Ahmadin, and Asmunandar. 2019. Modernization of Agricultural Equipment Cikoro Gowa 2005-2015. Journal of Historical Education and Research Thought Volume 6 No.1 January-March 2019.

12. Patiung, M., 2015. Strategy to Reduce Post-harvest Losses Through Technology Development in Tuban Regency. Scientific Journal of Socio Agribis Vol 15 No 2, December 2015.

13. Puspitasari, I., Harry J. Sumampouw, and Aneke Y. Punuindoong. 2018. Effect of Product Quality And Price Conformity On Increased Sales of Premium Rice In Perum Bulog Regional Division of North Sulawesi And Gorontalo (Case Study on Consumers of Manado City Area). Journal of Business Administration Vol. 6 No. 2, 2018

14. Rifkian, Bayu E., Pudjo Suharso, Sukidin. 2017. Agricultural Modernization (Case Study on Employment Opportunities and Income of Farmers in Agricultural System in Dukuhdempok Village, Wuluhan District, Jember Regency). Journal of Economic Education: Scientific Journals of Education, Economics, and Social Sciences Volume 11 Number 1. Jember.

15. Rerkesem, B., 2017. The Rice Value Chain: a Case Study of Thai Rice. ASR: CMU Journal of Social Sciences and Humanities (2017) Vol.4 No.1.

16. Selvia. Sisca, H. Jamaluddin Hos, and H. Sulsalman Moita.2019. The Impact of Agricultural Modernization on The Socioeconomic Condition of Rice Farmers (Study in Masagena Village, Konda District, South Konawe Regency). Neo Societal; Vol. 4; No. 2; April 2019

17. Swastika, DKS. 2012. Rice Harvest and Post-harvest Tech: Adoption Constraints and Development Strategy Policy. Center for Socioeconomic and Agricultural Policy. Bogor. 